\title{
Effect of Climatic Conditions on Tree-Ring Widths in Black Locust (Robinia pseudoacacia L.) in the city of Wroctaw
}

\section{Utjecaj klimatskih uvjeta na širinu godova bagrema (Robinia pseudoacacia L.) u gradu Wroclawu}

\author{
Original scientific paper • Izvorni znanstveni rad \\ Received-prispjelo: 19. 2. 2015. \\ Accepted-prihvaćeno: 29. 1. 2016. \\ UDK: $630 * 811.4 ; 630 * 814.11 ; 674.031 .739 .12$ \\ doi:10.5552/drind.2016.1512
}

\begin{abstract}
The response of trees to weather conditions, expressed in the tree-ring widths, depends on the extent of urbanization in the area. Specific climatic conditions in an urban heat island can be expected to result in growth differences to trees growing in non-urban areas. Accordingly, the aim of this study was to characterize the effect of climatic conditions on tree-ring widths of black locust in the city of Wrockaw. Materials consisted of wooden discs taken from felled trees at four sampling sites (4 streets of Wroctaw) at a height of $1.3 \mathrm{~m}$ from the ground. Meteorological data were obtained for the period 1971-2013 from the Institute of Meteorology and Water Management (IMGW) in Wroctaw. Analysis of the multiannual period showed a significant negative trend in annual ring widths of black locust in the city of Wroctaw. A code WROB was assigned to the chronology. The annual ring widths averaged $3.4 \mathrm{~mm}$, ranging from 1.6 to $5.6 \mathrm{~mm}$. In the urban conditions of Wroctaw, the air temperature and precipitation significantly influenced the annual ring widths of black locust. The results indicate the need for further research on a larger number of samples.
\end{abstract}

Key words: dendroclimatology, local chronology, regression analysis, south-western Poland, urban area

SAŽETAK • Odgovor stabala na vremenske uvjete, izražen širinom godova, ovisi o stupnju urbanizacije prostora u kojem drveće raste. Može se očekivati da će posebni klimatski uvjeti u urbanome toplom otoku rezultirati različitim rastom stabala u odnosu prema stablima u neurbaniziranim područjima. Prema tome, cilj ovog rada bio je istražiti utjecaj klimatskih uvjeta na širinu godova stabala bagrema u gradu Wroclawu. Istraživanje je provedeno na drvnim diskovima izrađenima od stabala posječenih na četiri mjesta uzorkovanja (u četiri ulice Wroclawa) na visini 1,3 m od tla. Meteorološki podaci za razdoblje 1971. - 2013. dobiveni su od Instituta za meteorologiju $i$ vodno gospodarstvo (IMGW) u Wroclawu. Analiza višegodišnjeg razdoblja pokazala je značajan negativni trend godišnjih širina godova bagrema u gradu Wroclawu. Kronologiji je dodijeljena šifra WROB. Prosječna godišnja širina goda iznosi 3,4 mm, a širine godova kreću se od 1,6 do 5,6 mm. U urbanim uvjetima Wroclawa temperatura

\footnotetext{
${ }^{1}$ Authors are professor, $\mathrm{PhD}$ and $\mathrm{PhD}$ student at Faculty of Environmental Engineering and Geodesy, Institute of Landscape Architecture at Wrocław University of Environmental and Life Sciences, Wrocław, Poland.

Autori su profesor, doktorica znanosti i doktorandica Fakulteta ekoinženjerstva i geodezije, Zavod za krajobraznu arhitekturu, Sveučilište okolišnih i bioloških znanosti, Wrocław, Poljska.
} 
zraka i količina oborina znatno su utjecale na godišnju širinu godova drva bagrema. Rezultati upućuju na potrebu nastavka istraživanja na većem broju uzoraka.

Ključne riječi: dendroklimatologija, lokalna kronologija, regresijska analiza, jugozapadna Poljska, gradsko područje

\section{INTRODUCTION}

\section{UVOD}

Black locust (Robinia pseudoacacia L.) was one of the first North American forest species introduced in Europe (Boring and Swank, 1984). Its natural range includes the eastern and central parts of the United States: the Appalachian Mountains, the Ozark Plateau and Ouachita Mountains (Feldhake, 2001; Call, 2002; Zajączkowski and Wojda, 2012). In the area of modern Poland, black locust was first planted in the $19^{\text {th }}$ century. Since then, it has spread in Poland, not only through artificial plantings but also via self-seeding (Ślusarczyk, 2012). Currently, it can be found almost everywhere in the country, with the highest concentrations in the western part, in both deciduous and coniferous forests (Wojda et al., 2014). Outside forest ecosystems, black locust can also be found in buffer strips, roadsides, shelter belts and city alleys (Łukaszewicz, 2010). It is especially appreciated in the reconstruction of historical parks and gardens (Majdecki, 1993). In the light of recent research, black locust can also be recommended as an energy crop in harsh habitat conditions, where it can be competitive with other energy crops (Rédei et al., 2010; Böhmi et al., 2011; Kraszkiewicz, 2013; Stolarski et al., 2013).

The response of trees to weather, especially the air temperature and precipitation, expressed in treering widths and the course of phenological phases, changes under the influence of human impact in the area (Walkovszky, 1998; Gillner et al., 2014). Trees from urban heat islands are expected to show differences in this respect compared to trees growing in nonurban areas. However, the dendroclimatological analysis of trees from urban areas has been poorly researched so far (Cedro and Nowak, 2006; Meier and Scherer,
2012). Namely, most commonly studied are trees growing within their natural ranges in the open landscape, and far less often trees that can be found outside the natural range (Tsakov and Alexandrov, 2005; Feldhake, 2001; Zhang et al., 2013; Čufar et al., 2014).

Therefore, the aim of this study was to characterize the time course of the tree ring widths of black locust in the urban environment of the city of Wrocław and assess its relations with the air temperature and precipitation.

\section{MATERIAL AND METHODS \\ 2. MATERIJAL I METODE}

Samples were made from 16 black locust trees located in four streets in Wrocław: Sucha (WS), Długa (WD), Witelona (WW) and Krucza (WK) (Figure 1). Individual sequences of ring widths are given in parentheses. Each tree was assigned a symbol and a number (1 to 16); for example WK15 and WK16 denoted trees felled in Witelota Street (Figure 2). Habitat conditions were similar in all sampling sites, with a predominance of surface covered by concrete and tarmac, etc., and low share of soils with open access to rainwater and sunlight. Discs were taken from trees at a height of 1.3 $\mathrm{m}$ above the ground. After drying and polishing the discs, the widths of tree-rings were measured in millimetres. The planned felling of the trees in 2014 provided the opportunity to obtain the disc samples, based on administrative decisions issued by the authorized body of the City of Wrocław. Direct sampling was performed by the arborysta.com company.

Meteorological data for the period 1971-2013, i.e. the average air temperature (Ta - analyzed year, PTa - previous year, ${ }^{\circ} \mathrm{C}$ ) and total precipitation ( $\mathrm{Rf}$ analyzed year, PRf - previous year, $\mathrm{mm}$ ) were obtained

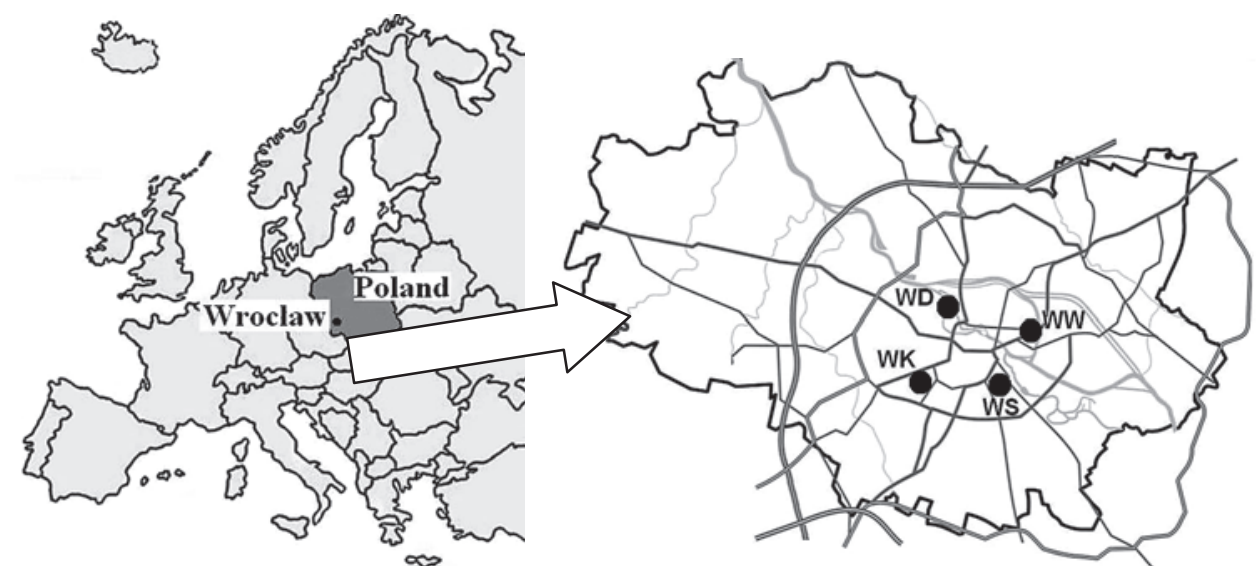

Figure 1 Location of the research area (WS, WD, WW, WK) in Wroclaw (south-western Poland). WS - Sucha street, WD - Długa street, WW - Witelona street, WK - Krucza street Slika 1. Lokacija područja istraživanja (WS, WD, WW, WK) u Wroclawu (sjeverozapadna Poljska); WS - ulica Sucha, WD - ulica Długa, WW - ulica Witelona, WK - ulica Krucza 
... Kalbarczyk, Ziemiańska, Machowska: Effect of Climatic Conditions on Tree-Ring Widths...

WROB

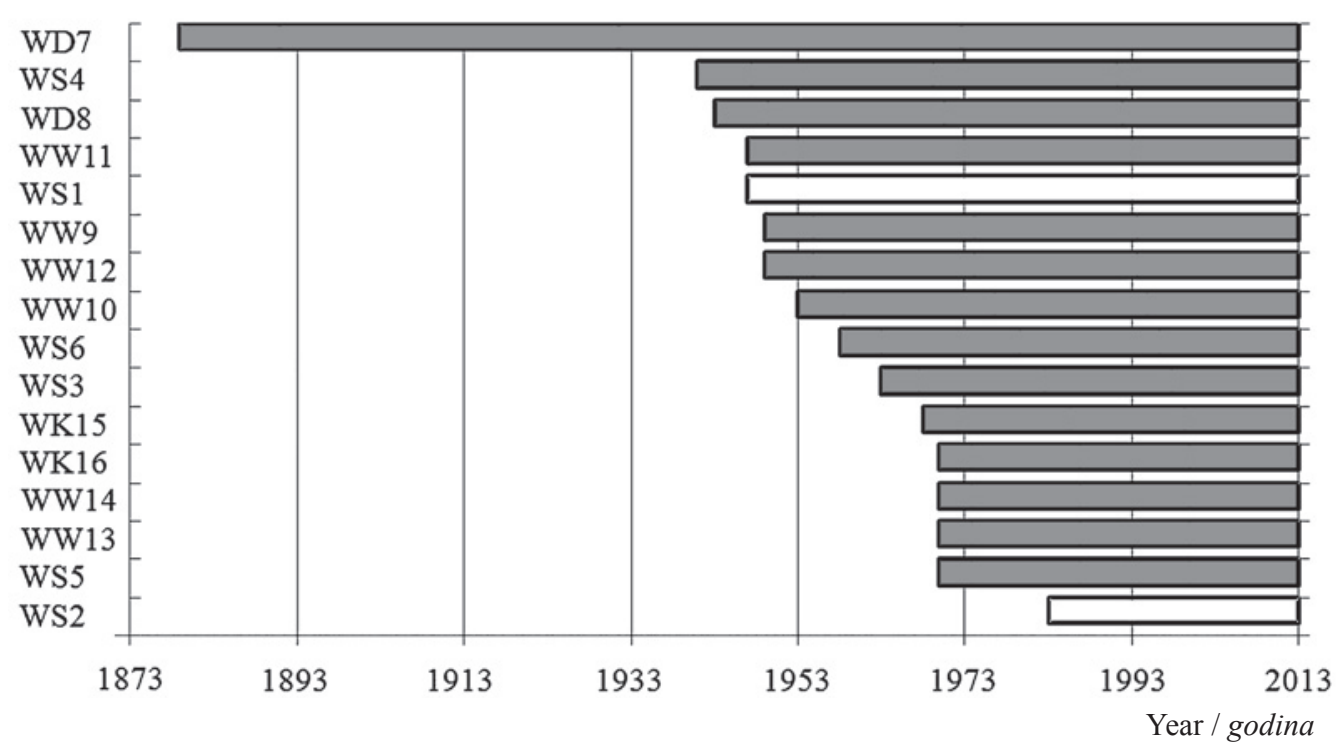

Figure 2 Dendrochronological dating of sequence included in the local chronology of black locust WROB. WS1, WS2 - sequences excluded from statistical analysis

Slika 2. Dendrokronološki slijed sekvenci uključenih u lokalnu kronologiju bagrema WROB; WS1, WS2 - sekvence isključene iz statističke analize

from the Institute of Meteorology and Water Management (IMGW) in Wrocław.

The individual sequences of tree-ring widths in black locust were used to assess similarities in the chronology of the analyzed trees (Figure 2). The most outlying sequences, WS1 and WS2, were excluded from further analysis due to a weak relationship with the pattern observed for the entire group of 16 trees. Local chronology was then established based on a correlation analysis and Student's $t$ test performed on the remaining group of 14 trees. The sequences of ring widths were used to determine the local chronology. The individual sequences of 14 trees, as well as a local chronology of black locust WROB, are presented using the following statistical indicators: mean values $(\overline{\mathrm{x}})$, standard deviation (Sd) and minimum (Min) and maximum (Max) values. Additionally, for annual ring widths, their prevalence was determined in one millimetre intervals, while for the local chronology the following parameters were determined: skewness, kurtosis, first-order autocorrelation $\left(r_{a}\right)$, correlation coefficient (r) for linear trend, deviations from the long-term average in the period 1971-2013 ( $\triangle$ WROB), and differences between successive years of WROB tree ring widths in the local chronology $(\triangle \mathrm{yWROB})$.

To evaluate the effect of the air temperature and precipitation on the annual ring width of black locust, master chronology was used, i.e. the arithmetic average of the 14 ring width sequences of the analyzed tree species. First, the chronology was transformed into an indexed chronology by removing the linear trend and long-term fluctuations, according to the formula proposed by Fritts (1976), and also after removing the first order autocorrelation in the residual chronology (Koprowski, 2006; Speer, 2010; Bijak et al., 2012).

The evaluation of the accuracy of the relationship between annual ring widths and air temperature and precipitation in the period 1971-2013 was determined using a Pearson's correlation coefficient (Dobosz, 2001). Assessment of the combined influence of meteorological conditions was performed using the multiple stepwise regression equation. Multiple regression parameters were determined by the method of least squares. Fit of the regression to the empirical data was measured by the coefficient of determination $R^{2}(\%)$ with the error of the regression equation $S y(\mathrm{~mm})$. A variable partial correlation analysis was used to determine the contribution of each of the selected factors to the prediction of the explanatory variable. The calculated partial correlation coefficients were squared and expressed in \% (as $\left.r^{2}\right)$. In the correlation and regression analyses, the dependent variable was annual tree ring widths in the form of residual chronology, while the independent variable was meteorological elements from the months of the current year (from January to September) and the previous year (June to December). Similar periods were taken into account in dendroclimatic studies by Fritts (1976), Cedro and Nowak (2006) and Koprowski (2012). Statistical analyses were performed using STATISTICA 10. The scientific name of the analyzed tree species was taken from "Dendrology" by Seneta and Dolatowski (2009).

\section{RESULTS}

\section{REZULTATI}

The local chronology of black locust with the signature WROB for four sampling sites (WS, WD, WW, WK) located in the main streets in Wrocław was 134 years in length and represented the period 1880-2013 (Figure 2, Figure 3). The longest dendrogram (WD7) equalled the local chronology, while the shortest ones (WS5, WW13, WW14 and WK16) were 43 years in length (1971-2013). 


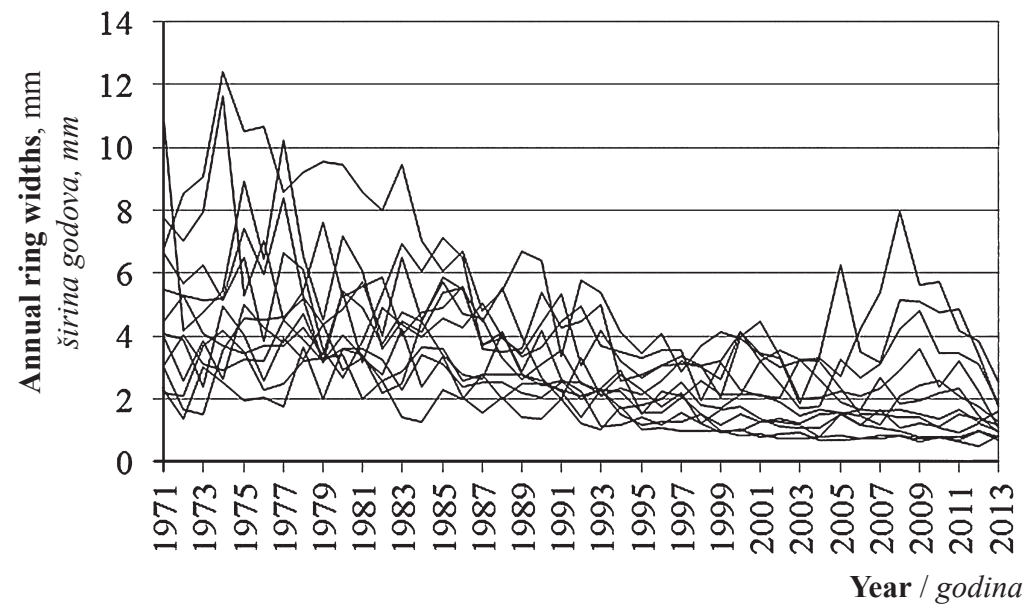

Figure 3 Dendrochronological curves included in the local chronology of black locust WROB. Years 1971-2013 Slika 3. Dendrokronološke krivulje uključene u lokalnu kronologiju bagrema WROB; razdoblje 1971. - 2013.

In the period 1971-2013, the tree-ring widths were widest in the tree WS3 $(6.0 \mathrm{~mm})$ followed by the trees WS5 and WK16 (4.4 and $4.2 \mathrm{~mm}$, respectively) (Figure 4). The variability of annual ring widths, expressed as standard deviation, ranged from $0.7 \mathrm{~mm}$ (WS7) to $2.6 \mathrm{~mm}$ (WS3). Both the maximum and minimum annual ring widths in individual trees included in the local chronology varied significantly. Maximum annual ring widths ranged from $3.7 \mathrm{~mm}$ (WS6) to 12.4 $\mathrm{mm}$ (WS3), whereas minimum ring widths ranged from $0.5 \mathrm{~mm}$ (WD8) to $2.6 \mathrm{~mm}$ (WS3).

Diagrams showing the incidence of tree-rings in the adopted ranges revealed that over $77 \%$ of all growth rings obtained in the years 1971 to 2013 ranged from 1 to $5 \mathrm{~mm}$ (Figure 5). Lower $(<1 \mathrm{~mm})$ and higher ranges (from 5 to $6 \mathrm{~mm}$ ) showed a significantly lower incidence (about $5 \%$ and $8 \%$, respectively). Growth rings wider than $6 \mathrm{~mm}$ occurred in $9 \%$ of cases, while those $>10 \mathrm{~mm}$ occurred in only $1 \%$ of cases. The lower quartile for each dendrochronological curve ranged from $0.9 \mathrm{~mm}$ (WD8, WW9) to $3.9 \mathrm{~mm}$ (WS3), and the upper quartile from $2.5 \mathrm{~mm}$ (WD7) to $8.4 \mathrm{~mm}$ (WS3). The interquartile range varied from 1.0 (WS6) to 4.5 $\mathrm{mm}$ (WS3) and showed a moderate variability of annual growth rings among the individual sequences.

The average tree-ring width of black locust WROB for the period 1971-2013 was $3.4 \mathrm{~mm}$, with a standard deviation of $1.2 \mathrm{~mm}$ (Table 1). The narrowest absolute

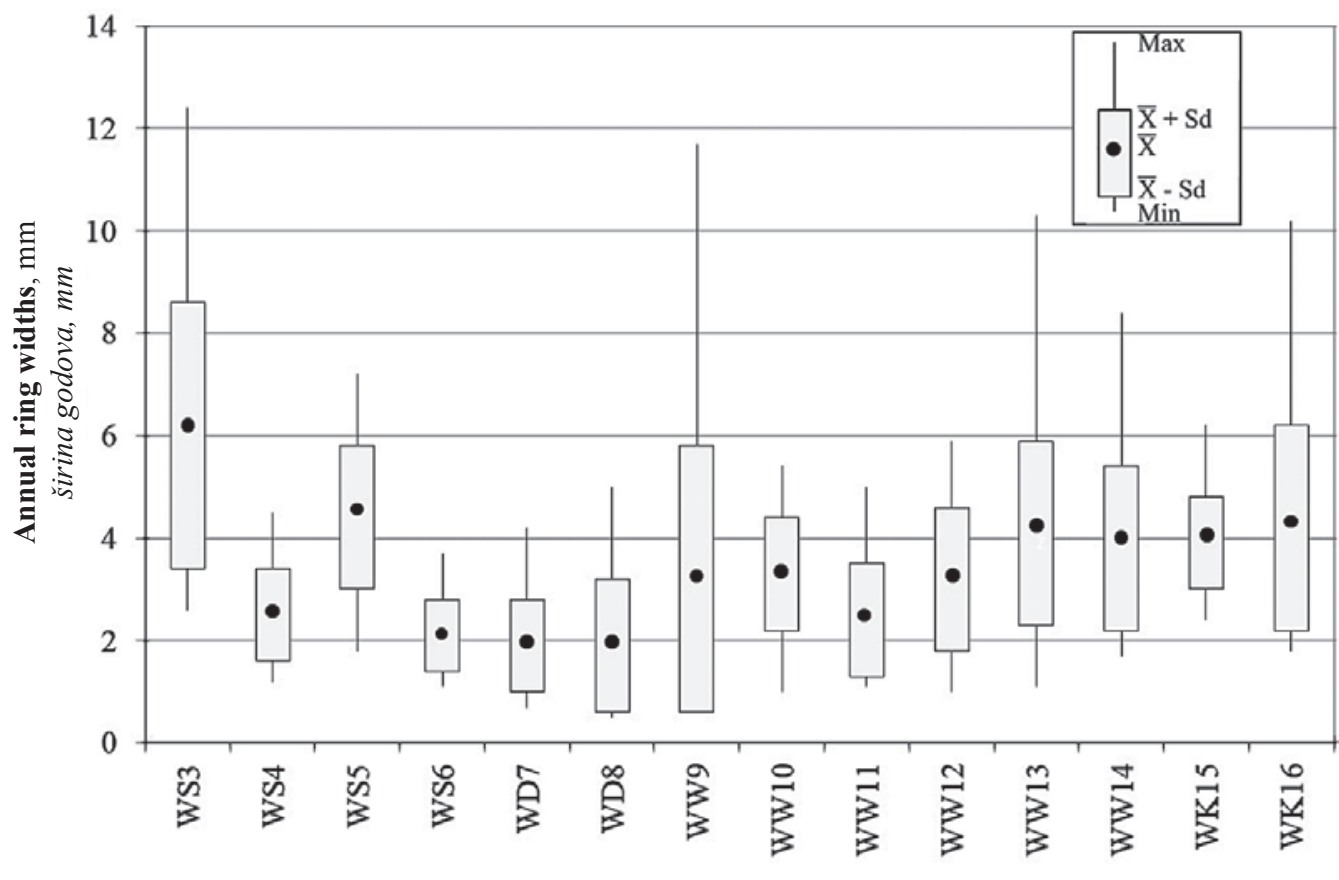

Sequences / sekvence

Figure 4 Statistical characteristics: $\bar{x}, S d$, Max, Min of annual ring width sequences included in the local chronology of black locust WROB. Years 1971-2013

Slika 4. Statistička obilježja $\bar{x}, S d$, Max, Min sekvenci godišnjih širina godova uključenih u lokalnu kronologiju bagrema WROB; razdoblje 1971. - 2013. 

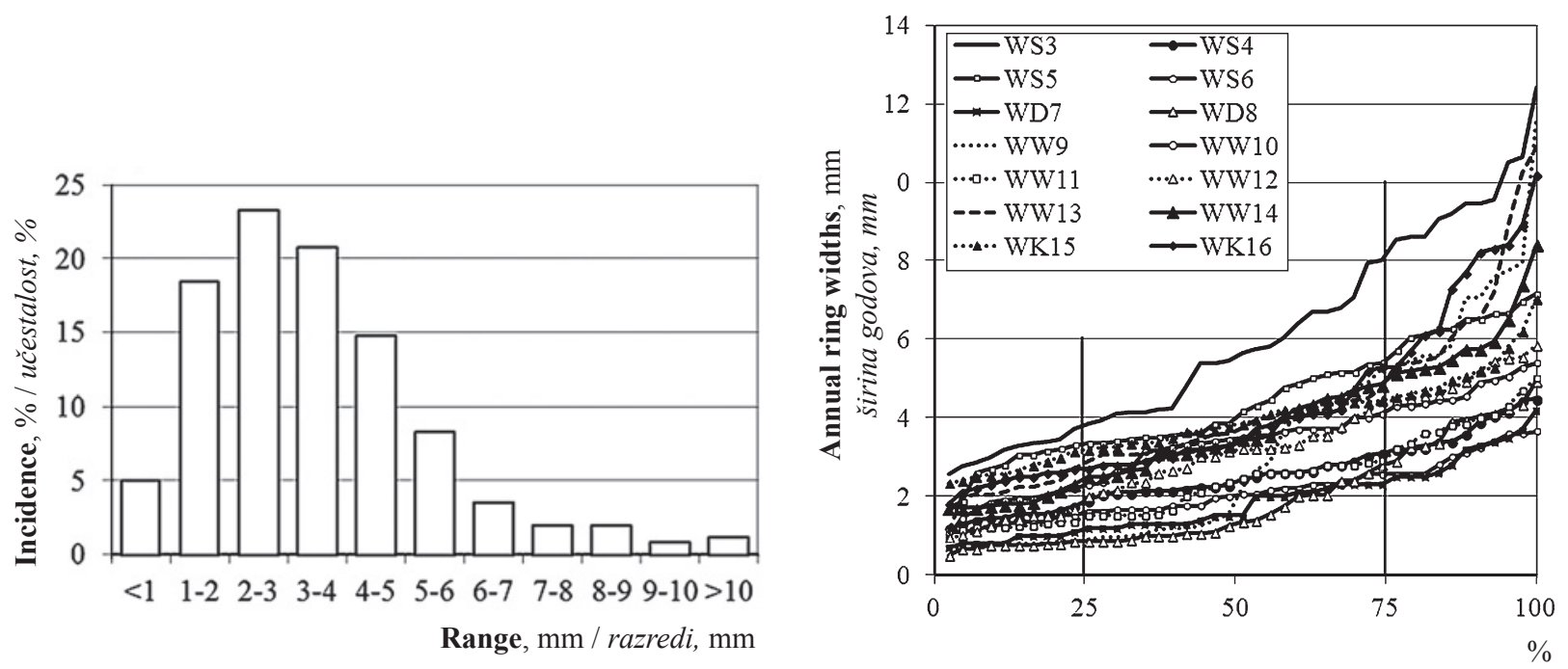

Figure 5 The incidence of tree ring width sequences included in the local chronology of black locust WROB. Years 19712013. Left side: distribution by ranges, right side: cumulative distribution

Slika 5. Učestalost sekvenci širine godova stabala uključenih u lokalnu kronologiju bagrema WROB; razdoblje 1971. -

2013.; lijeva strana - raspodjela prema razredu širine goda, desna strana - kumulativna distribucija

ring width $(1.6 \mathrm{~mm})$ was recorded in 2013 . The widest absolute ring width $(5.6 \mathrm{~mm})$ was observed in 1974 . In the analyzed period, the ring widths of black locust in Wrocław showed a significant, positive autocorrelation of the first order $\left(r_{\mathrm{a}}=0.89, P \geq 0.01\right)$ and a significant negative linear trend $(r=-0.93, P \geq 0.01)$. It was also found that the right side of the distribution of the local chronology WROB was more extended than the left side $(S \mathrm{k}=0.42)$, and that the distribution curve was flatter than in the normal distribution $(K=-1.31)$.

In the first 18 analyzed years (i.e. period 19711988), the deviation from the average ring width in local chronology WROB was positive and ranged from $0.1 \mathrm{~mm}$ in 1987 to $2.2 \mathrm{~mm}$ in 1974 (Figure 6). A nega-

Table 1 Statistical characteristics designated for the local chronology of black locust WROB. Years 1971-2013

Tablica 1. Statistička obilježja određena za lokalnu kronologiju bagrema WROB; razdoblje 1971. - 2013.

\begin{tabular}{|c|c|c|c|c|c|c|c|}
\hline \multirow{2}{*}{ Wronologija WROB } & \multicolumn{9}{|c|}{ Characteristics / Obilježja } \\
\cline { 2 - 8 } & $\begin{array}{c}\bar{x} \pm \text { Sd } \\
\mathrm{mm}\end{array}$ & $\begin{array}{c}\text { Min/Year } \\
\text { Min/god. } \\
\mathrm{mm}\end{array}$ & $\begin{array}{c}\text { Max/Year } \\
\text { Maks./god. } \\
\mathrm{mm}\end{array}$ & $S k$ & $K$ & $\begin{array}{c}\text { autocorrelation } \\
\text { of the first order } \\
\text { autokorelacija prvog reda }\end{array}$ & $\begin{array}{c}r \text { for linear trend } \\
\text { za linearni trend }\end{array}$ \\
\hline & $3.4 \pm 1.204$ & $1.6 / 2013$ & $5.6 / 1974$ & 0.42 & -1.31 & $0.89^{* * *}$ & $-0.93^{* * * *}$ \\
\hline
\end{tabular}

*** significant at $P \geq 0.01$ / signifikantno pri $P \geq 0.01, \bar{x}$ - average / srednja vrijednost $(\mathrm{mm}), S d$ - standard deviation / standardna devijacija $(\mathrm{mm})$, Min - minimum value / minimalna vrijednost $(\mathrm{mm})$, Max - maximum value / maksimalna vrijednost $(\mathrm{mm})$, Sk - skewness / asimetrija, $K$ - curtosis / oštrina vrha krivulje frekvencijske distribucije

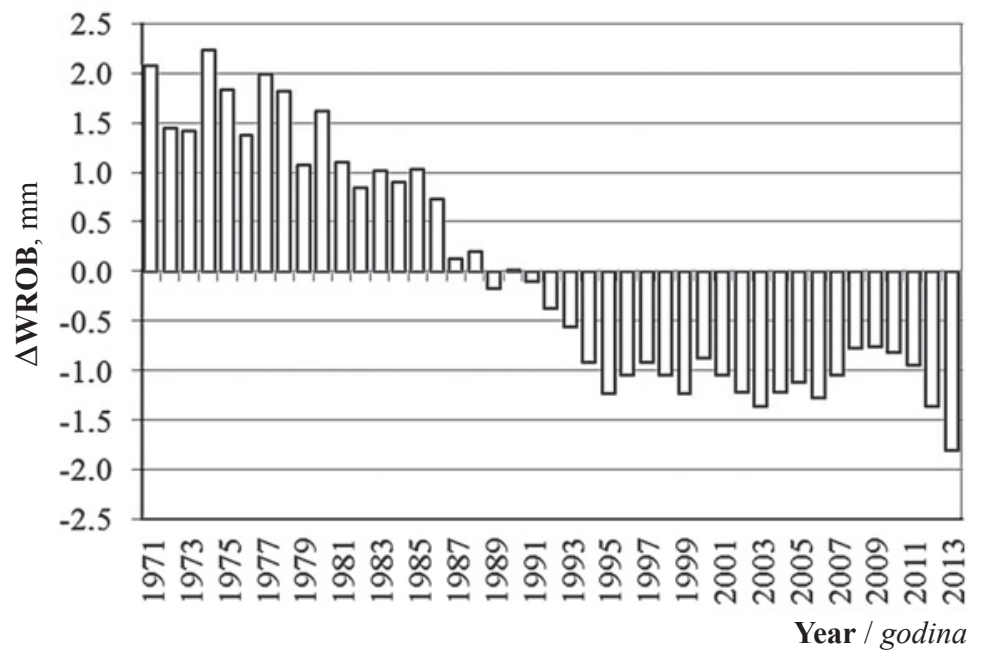

Figure 6 Deviations from the long-term average (1971-2013) of the annual ring widths ( $\triangle$ WROB) in the local chronology of black locust WROB. Years 1971-2013

Slika 6. Odstupanja od dugoročnog prosjeka (1971. - 2013.) godišnjih širina godova ( $\triangle$ WROB) u lokalnoj kronologiji bagrema WROB; razdoblje 1971. - 2013. 


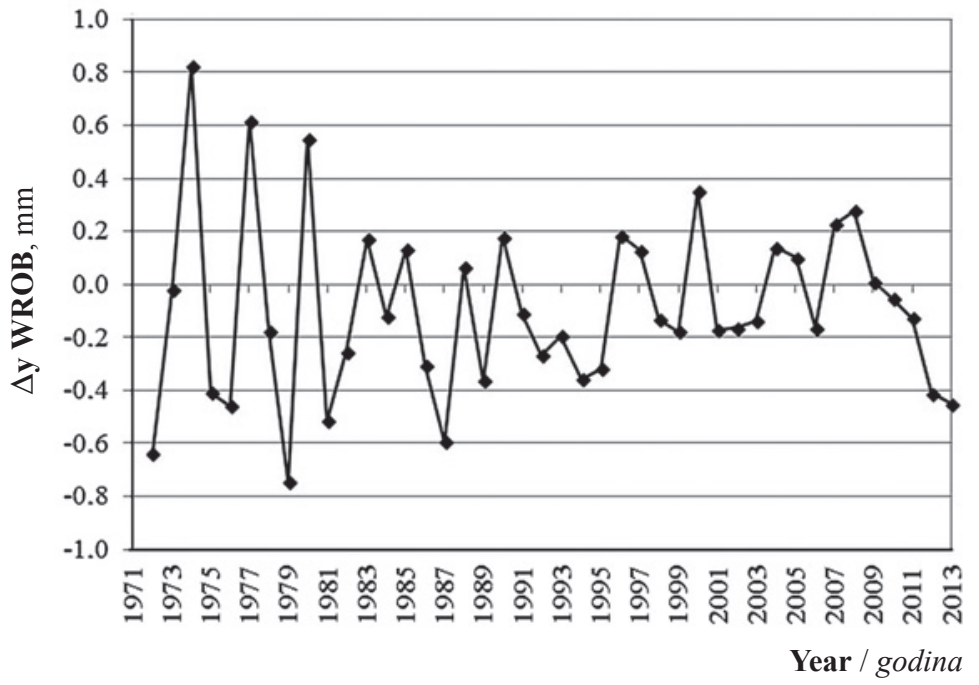

Figure 7 Differences between successive years in ring widths $(\Delta y)$ in the local chronology of black locust WROB. Years 1971-2013

Slika 7. Razlike u širini godova između uzastopnih godina $(\Delta y)$ u lokalnoj kronologiji bagrema WROB; razdoblje 1971. - 2013.

tive deviation was observed in the period 1989-2013 (with the exception of 1990, in which the deviation was $0 \mathrm{~mm}$ ); the highest deviation was observed in 2013 (-1.8 $\mathrm{mm})$. Differences were also found between adjacent years ranging from $-0.7 \mathrm{~mm}$ between 1979 and 1978 to $0.8 \mathrm{~mm}$ between 1974 and 1973 (Figure 7). The differences, both positive and negative, were distinctly higher in the first half of the analyzed period. In 14 years, growth ring widths were wider than in the previous year, and in only two years they were identical to the previous years.

Annual ring widths of black locust in Wrocław WROB depended on the air temperature and precipitation (Figure 8). The annual ring widths in urban conditions correlated negatively with the air temperature in May-September of the analyzed year, and in December and August of the previous year, while they correlated positively with the air temperature in January-April of the analyzed year and in the period June-July and September-November of the previous year. Among the analyzed 16 months, only three months of the analyzed year demonstrated a significant effect of thermal conditions on tree-ring widths: positive in February (Ta2, $r=0.29, P \geq 0.05)$ and March (Ta3, $r=0.28, P \geq 0.05)$, negative in July ( $T a 7$, $r=-0.34, P \geq 0.01)$.

In the years 1971-2013, precipitation positively influenced ring widths in February-March and May-August of the analyzed year and in the period June and September-November of the previous year, while negatively in January, April and September of the analyzed year and in the period July-August and in December of the previous year. A significant relationship was found in September $(R f 9, r=-0.35, P \geq 0.01)$ of the analyzed year

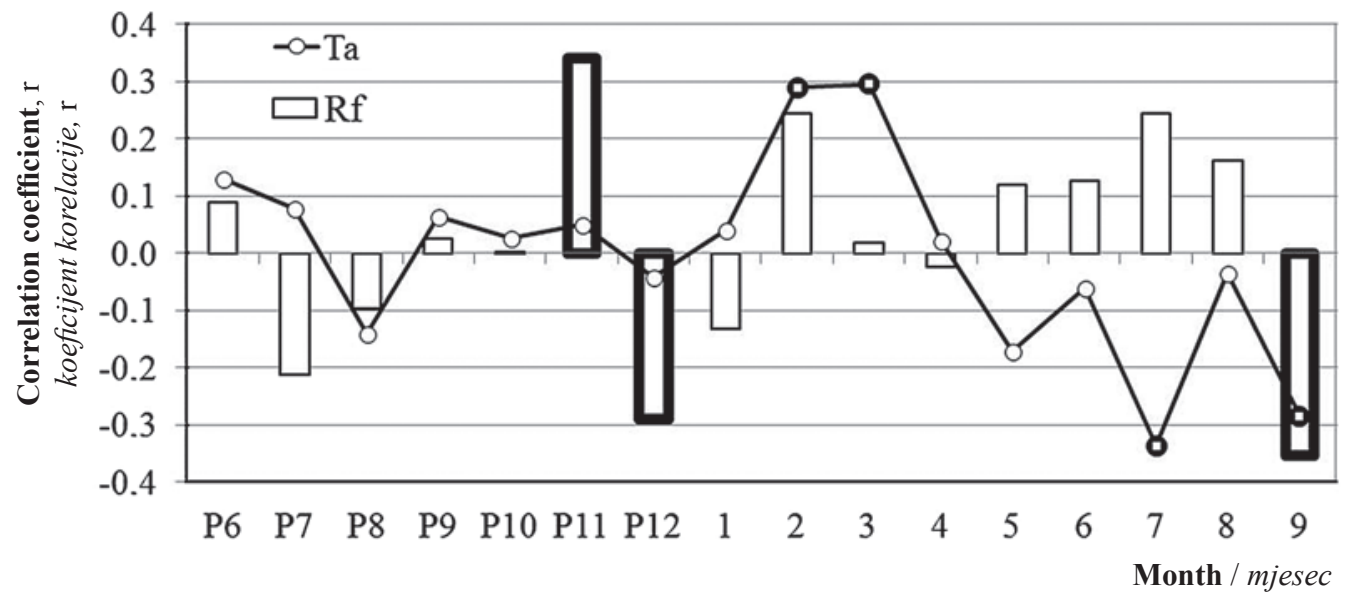

Figure 8 Relationship between residual ring widths in the local chronology of black locust WROB and the air temperature $\left(\mathrm{Ta},{ }^{\circ} \mathrm{C}\right)$ and total precipitation $(R f, \mathrm{~mm})$. Years 1971-2013. Bold line indicates a significant correlation at least at $P \geq 0.05$; $P 6, P 7 \ldots P 12$ - month of the previous year, $1,2 \ldots 9$ - month of current year

Slika 8. Odnos između preostale širine godova u lokalnoj kronologiji bagrema WROB i temperature zraka $\left(\mathrm{Ta},{ }^{\circ} \mathrm{C}\right)$ te ukupnih oborina $(R f, \mathrm{~mm})$; razdoblje 1971. - 2013.; zadebljane linije označavaju signifikantnu korelaciju barem na $P \geq 0,05$; $P 6, P 7$... P12 - mjesec prethodne godine; $1,2 \ldots 9$ - mjesec tekuće godine 
Table 2 Evaluation of the combined effect of air temperature and precipitation on residual annual ring widths in the local chronology of black locust WROB based on multiple stepwise regression equation. Years 1971-2013

Tablica 2. Procjena kombiniranog utjecaja temperature zraka i oborina na preostale godišnje širine godova u lokalnoj kronologiji bagrema WROB na temelju stupnjevite regresijske jednadžbe; razdoblje 1971. - 2013.

\begin{tabular}{|c|c|c|c|c|c|c|c|}
\hline \multirow{2}{*}{$\begin{array}{l}\text { Variable } \\
\text { Varijabla }\end{array}$} & \multicolumn{3}{|c|}{$\begin{array}{l}\text { Indicators describing independent variables of the equation } \\
\text { Indikatori koji opisuju neovisne varijable jednadžbe }\end{array}$} & \multicolumn{4}{|c|}{$\begin{array}{l}\text { Indicators describing the equation } \\
\text { Indikatori koji opisuju jednadžbu }\end{array}$} \\
\hline & $\begin{array}{l}r^{2} \\
\%\end{array}$ & $t$ & $P$ & $F$ & $\begin{array}{l}R^{2} \\
\%\end{array}$ & $\begin{array}{c}S d-S y \\
\mathrm{~mm}\end{array}$ & $\begin{array}{c}\text { Sy } \\
\mathrm{mm}\end{array}$ \\
\hline PRf11 & 11.6 & 2.2 & 0.05 & \multirow{6}{*}{5.4} & \multirow{6}{*}{29.9} & \multirow{6}{*}{0.012} & \multirow{6}{*}{0.082} \\
\hline PRf12 & 12.2 & -2.3 & 0.05 & & & & \\
\hline$R f 9$ & 14.9 & -2.6 & 0.01 & & & & \\
\hline Ta2 & & & n.s. & & & & \\
\hline Ta3 & & & n.s. & & & & \\
\hline$T a 7$ & & & n.s. & & & & \\
\hline
\end{tabular}

PRf11/PRf12 - precipitation in November/December of the previous year / oborine u studenome/prosincu prethodne godine (mm); Rf9 - precipitation in September of the current year / oborine u rujnu tekuće godine (mm); Ta2/Ta3/Ta 7 -air temperature in February/March/July of the current year / temperatura zraka u veljači/ožujku/srpnju tekuće godine $\left({ }^{\circ} \mathrm{C}\right) ; r^{2}$ - square of partial correlation coefficient of $\mathrm{x}$, y variables / $k v a d r a t$ djelomičnog koeficijenta korelacije $x$, y varijable (\%); $\mathrm{t}$ - Student's $t$-test / Studentov t-test; $P$ - level of significance/ razina značajnosti; n.s. - non-significant at $P \geq 0.1$ / nesignifikanto pri razini $P \geq 0.1 ; F$ - Snedocor's $F$-test / Snedecorov F-test; $R^{2}$ - determination coefficient / koeficijent determinacije (\%); Sd-Sy-difference between a standard deviation of a dependent variable and a standard error of equation estimation / razlika između standardne devijacije zavisne varijable i standardne pogreške procjene jednadžbe (mm), Sy - standard error of equation estimation / standardna pogreška procjene jednadžbe $(\mathrm{mm})$

and in November $(P R f 11, r=0.34, P \geq 0.01)$ and December $(P R f 12, r=-0.29, P \geq 0.05)$ of the previous year.

Multiple regression analysis, showing the combined effect of weather conditions (precipitation and air temperature) on ring widths, indicated that the biggest impact was exerted by precipitation in three months: PRf11, PRf12 and Rf9, while thermal conditions proved to be insignificant (Table 2). Precipitation, significant at $p \geq 0.05$, determined the annual ring widths in black locust by about $30 \%$; the greatest impact was shown by $R f 9\left(r^{2}=14.9 \%, P \geq 0.05\right)$.

Precipitation in months that significantly contributed to a reduction in annual ring widths, averaged approximately $35 \mathrm{~mm}$ in $P R f 12$ and about $50 \mathrm{~mm}$ in $R f 9$ (Table 3). The highest precipitation in PRf12 and Rf 9 amounted to $100 \mathrm{~mm}$ in 1975 and $110 \mathrm{~mm}$ in 2013, with the lowest (4 mm) in 1973 and $7 \mathrm{~mm}$ in 1975. The precipitation in PRf11 was characterized by a significantly lower variability (by about 10-20 \%) than PRf12 and $R f 9$, and a significant negative trend in the years 1971-2013 ( $r=0.35, P \geq 0.05)$. The extreme levels of PRf11 were the lowest among the three analyzed months $(\operatorname{Max}=98 \mathrm{~mm}, \operatorname{Min}=2 \mathrm{~mm})$.

\section{DISCUSSION 4. RASPRAVA}

There are few papers on the variability of annual ring widths of trees in the technosphere and its dependence on meteorological conditions. This is mainly due to the difficulty in obtaining permission from the local authorities for sampling with the use of a Pressler drill, and also due to the difficulty in collecting the appropriate sample size from a given type of sampling site (with similar conditions of growth and development for a given tree species). Trees in urban areas, including black locust, are exposed to many adverse environmental factors influencing the course of their vegetation, as reflected, for example, in tree-ring width. The most important include the deteriorated quality and quantity of soil, pollution of the ground with debris, calcium, chlorine and sodium ions, as well as altered meteorological parameters (Szczepanowska, 2001; Łukasiewicz, 2010; Rahmana et al., 2014).

Most publications in the field of biology and dendroclimatology deal with trees in forests outside urbanized areas. Although research on black locust has been

Table 3 Statistical characteristics designated for precipitation (PRf, Rf, mm) significantly influencing (in the entire system of meteorological elements) the annual ring widths in the local chronology of black locust WROB. Years 1971-2013

Tablica 3. Statistička obilježja određena za oborine (PRF, RF, mm) koje znatno utječu (u cijelom sustavu meteoroloških elemenata) na širinu goda u lokalnoj kronologiji bagrema WROB; razdoblje 1971.-2013.

\begin{tabular}{|c|c|c|c|c|c|c|}
\hline \multirow{3}{*}{$\begin{array}{l}\text { Variable } \\
\text { Varijabla }\end{array}$} & \multicolumn{6}{|c|}{ Characteristics / Obilježja } \\
\hline & $\overline{\mathrm{x}} \pm \mathrm{Sd}$ & $\begin{array}{l}\text { Min/Year } \\
\text { min./god. }\end{array}$ & $\begin{array}{l}\text { Max/Year } \\
\text { maks./god. }\end{array}$ & $\begin{array}{l}\text { Range } \\
\text { raspon }\end{array}$ & \multirow{2}{*}{$\begin{array}{l}V \\
\%\end{array}$} & \multirow{2}{*}{$\begin{array}{l}r \text { for linear trend } \\
r \text { za linearni trend }\end{array}$} \\
\hline & \multicolumn{4}{|c|}{$\mathrm{mm}$} & & \\
\hline PRf11 & $38.8 \pm 18.4$ & $2.0 / 2012$ & 98.0/1971 & 96.0 & 47.5 & $-0.35^{* *}$ \\
\hline PRf12 & $34.5 \pm 20.4$ & $4.0 / 1973$ & $100.0 / 1975$ & 96.0 & 59.4 & n.i. \\
\hline$R f g$ & $49.6 \pm 29.9$ & $7.0 / 1982$ & $110.0 / 2013$ & 103.0 & 60.2 & n.i. \\
\hline
\end{tabular}

$V$ - coefficient of variability / koeficijent varijabilnosti (\%), ** significant at $P \geq 0.05$ / signifikantno pri $P \geq 0,05$; for further explanations see Table 1/ druga objašnjenja pogledati u tablici 1. 
carried out for example by Boring and Swank (1984), Farrar and Evert (1997), Feldhake (2001), Zhang et al. (2013), and Wang et al. (2013), a completely different climate and locations in those studies do not allow for comparison of their results with our paper. In the period 1971-2013, the average annual ring width of black locust in the sampling sites in Wrocław was $3.4 \mathrm{~mm}$, ranging from 1.6 to $5.6 \mathrm{~mm}$. Similar values, obtained in a forest in SE Poland (Forest District Krosno), were recorded by Feliksik et al. (2007), where the average annual ring width was $3.3 \mathrm{~mm}$ and ranged from 1.2 to $5.9 \mathrm{~mm}$. It should be emphasized that comparisons concerning average tree-ring widths are especially prone to error. The average ring width at individual sampling sites does not take into account the differences arising from the age of the trees and the habitat conditions (Cailleret and Davi, 2011). The dendroclimatological analysis of the relationship between weather conditions and annual ring width in 1971-2013 indicates a significant influence of the air temperature and precipitation on the ring width of black locust. The air temperature, lower than the average in JanuaryApril (especially in February and March) and higher than the average in May-September (especially in July and September), adversely affected the tree-ring widths. A similar negative effect was induced by a wet September and December and a dry November. Similarly, Feliksik et al. (2007) found that cold winters and low air temperature in early spring, as well as low amount of precipitation during the summer (June-July), were the most important meteorological elements inhibiting the radial growth of black locust. The air temperature from late winter to early spring affects the physiological processes involved in the initiation of cambial cell production and in differentiation of xylem cells in the tree (Begum et al., 2013). Importantly, premature initiation of cambial activity increases the risk of damage to biomass growth because of a sudden drop in air temperature below the physiological tolerances of the tree. The climate in the natural range of the black locust is distinctly different in terms of air temperature and (especially) precipitation in comparison with the climate of south-western Poland (Boring and Swank 1984, Dubicki et al., 2002; Feliksik et al., 2007; Kalbarczyk, 2010). For example, the average air temperature in January in the eastern and central parts of the United States ranges from about $-4.0{ }^{\circ} \mathrm{C}$ to $+7.0{ }^{\circ} \mathrm{C}$, and in August from 18.0 to $27.0^{\circ} \mathrm{C}$ (Boring and Swank, 1984). Wrocław averages from $-9.0^{\circ} \mathrm{C}$ to $4.2{ }^{\circ} \mathrm{C}$ and from $15.9^{\circ} \mathrm{C}$ to $21.5^{\circ} \mathrm{C}$, respectively (Dubicki et al., 2002). The U.S. precipitation ranges between 1020$1830 \mathrm{~mm}$ and is on average about $250 \%$ higher than in Poland.

\section{CONCLUSION}

5. ZAKLJUČAK

In the years 1971-2013, a significant negative trend of annual ring width of black locust was observed in Wroclaw WROB. The annual growth averaged 3.4 $\mathrm{mm}$ and ranged from 1.6 to $5.6 \mathrm{~mm}$, most frequently ranging from 2 to $3 \mathrm{~mm}$. Differences between successive years ranged from $-0.7 \mathrm{~mm}$ between 1979 and 1978 to $0.8 \mathrm{~mm}$ between 1974 and 1973 .

In this study, a significant influence of air temperature and precipitation on the annual ring width of black locust was demonstrated. Multiple regression analysis showed that the annual ring widths of the analyzed tree species were mainly affected by precipitation in November and December of the previous year and September of the analyzed year, with different temporal distributions in individual years.

The results indicate that further research should be made on a larger number of samples.

\section{REFERENCES}

\section{LITERATURA}

1. Begum, S.; Nakaba, S.; Yamagishi, Y.; Oribe, Y., Funada, R., 2013: Regulation of cambial activity in relation to environmental conditions: understanding the role of temperature in wood formation of trees. Physiol. Plant 147: 4654. http://dx.doi.org/10.1111/j.1399-3054.2012.01663.x

2. Bijak, Sz.; Bronisz, A.; Bronisz, K., 2012: Wpływ ekstremalnych warunków klimatycznych na przyrost radialny dębu czerwonego Quercus rubra w LZD Rogów. Studia i Materiały CEPL w Rogowie, 33 (4): 160-167 (in Polish).

3. Boring, L. R.; Swank, W. T., 1984: The role of black locust (Robinia pseudoacacia) in forest succession. J. Ecol., 72: 749-766 http://dx.doi.org/10.2307/2259529.

4. Böhm, Ch.; Quinkenstein, A.; Freese, D., 2011: Yield prediction of young black locust (Robinia pseudoacacia L.) plantations for woody biomass production using allometric relations. Ann. For. Res., 54 (2): 215-227.

5. Cailleret, M.; Davi, H., 2011: Effects of climate on diameter growth of co-occurring Fagus sylvatica and Abies alba along an altitudinal gradient. Trees-Struct. Funct., 25 (2): 7-39 http://dx.doi.org/10.1007/s00468-010-0503-0.

6. Call, L. J., 2002: Analysis of intraspecific and interspecific interactions between the invasive exotic tree-ofheaven (Ailanthus altissima (Miller) Swingle) and the native black locust (Robinia pseudoacacia L.), Blacksbur - Virginia, Virginia Polytechnic Institute and State University, pp. 80 http://dx.doi.org/10.1007/s11258-004-0338-0.

7. Cedro, A.; Nowak, G., 2006: Effects of climatic conditions on annual tree ring growth of the Platanus $\times$ hispanica 'Acerifolia' under urban conditions of Szczecin. Dendrobiology, 55: 11-17.

8. Čufar, K.; Šefc, B.; De Luis, M.; Morgós, A.; Grabner, M.; Merela, M.; Trajković, J., 2014: Tree-ring chronology of pedunculate oak (Quercus robur) and its potential for development of dendrochronological research in Croatia. Drvna industrija, 65 (2): 129-137 http://dx.doi.org/10.5552/drind.2014.1337.

9. Dobosz, M., 2001: Wspomagana komputerowo statystyczna analiza wyników badań. Warszawa, Akademicka Oficyna Wydawnicza EXIT, pp. 452 (in Polish).

10. Dubicki, A.; Dubicka, M.; Szymanowska, M., 2002: Klimat Wrocławia. Środowisko Wrocławia - Informator 2002, Wrocław, Dolnośląska Fundacja Ekorozwoju, pp. 9-25 (in Polish).

11. Farrar, J. J.; Evert, R. F., 1997: Seasonal changes in the ultrastructure of the vascular cambium of Robinia pseudoacacia. Trees, 11: 191-202 http://dx.doi.org/10.1007/p100009667. 
... Kalbarczyk, Ziemiańska, Machowska: Effect of Climatic Conditions on Tree-Ring Widths...

12. Feldhake, C. M., 2001: Microclimate of a natural pasture under planted Robinia pseudoacacia in central Appalachia, Agroforest Syst., 53: 297-303 http://dx.doi. org/10.1023/a:1013331628494.

13. Feliksik, E.; Orzeł, S.; Wilczyński, S., 2007: Dendrometric and dendroclimatological analyses of Black Locust. EJPAU 10(2), \#07. Available Online:

http://www.ejpau.media.pl/volume10/issue2/art-07.html.

14. Fritts, H. C., 1976: Tree rings and climate. University of Arizona, Tuscon, Arizona The Blackburn Press, pp. 567.

15. Gillner, S.; Bräuning, A.; Roloff, A., 2014: Dendrochronological analysis of urban trees: climatic response and impact of drought on frequently used tree species. Trees, 28: 1079-1093 http://dx.doi.org/10.1007/s00468-014-1019-9.

16. Kalbarczyk, R., 2010: Spatial and temporal variability of the occurrence of ground frost in Poland and its effect on growth, development and yield of pickling cucumber (Cucumis sativus L.), 1966-2005. Acta Sci. Pol., Hortorum Cultus, 9 (3): 3-26 http://dx.doi.org/10.5424/sjar/2010084-1405.

17. Kraszkiewicz, A., 2013: Evaluation of the possibility of energy use black locust (Robinia pseudoacacia L.) dendromass acquired in forest stands growing on clay soils. J. Cent. Eur. Agr., 14 (1): 388-399 http://dx.doi.org/10.5513/jcea01/14.1.1212.

18. Koprowski, M., 2006: Dendrochronologiczna analiza przyrostów rocznych buka zwyczajnego (Fagus sylvatica L.)_w Nadleśnictwie Iława. Sylwan, 5: 44-50.

19. Koprowski, M., 2012: Long-term increase of march temperature has no negative impact on tree rings of European larch (Larix decidua) in lowland Poland. Trees, 26: 18951903 http://dx.doi.org/10.1007/s00468-012-0758-8.

20. Łukasiewicz, S., 2010: Drzewa i krzewy polecane do obsadzeń ulicznych w miastach. In: Drozdek M., E. (Ed.). Rośliny do zadań specjalnych, Sulechów. Wyd. PWSZ Sulechów: 313-324 (in Polish).

21. Majdecki, L., 1993: Ochrona i konserwacja zabytkowych założeń ogrodowych, Warszawa, PWN, pp. 386. (in Polish).

22. Meier, F.; Scherer, D., 2012: Spatial and temporal variability of urban tree canopy temperature during summer 2010 in Berlin, Germany. Theor. Appl. Climatol., 110: 373-384 http://dx.doi.org/10.1007/s00704-012-0631-0.

23. Rahmana, M. A.; Armsonb, D.; Ennos, A. R., 2014: Effect of urbanization and climate change in the rooting zone on the growth and physiology of Pyrus calleryana. Urban For. Urban Green, 13 (2): 325-335 http://dx.doi.org/10.1016/j.ufug.2013.10.004.

24. Rédei, K.; Veperdi, I.; Tomé, M.; Soares, P., 2010: Black locust (Robinia pseudoacacia L.) short-rotation energy crops in Hungary: A review. Silva Lusitana, 18 (2): $217-$ 223.

25. Seneta, W.; Dolatowski, J., 2009: Dendrologia. Warszawa. Wydawnictwo Naukowe PWN, pp. 308. (in Polish).
26. Speer, J. H., 2010: Fundamentals of tree-ring research. Tuscon. The University of Arizona. Press, pp. 333.

27. Stolarski, M. J.; Krzyżaniak, M.; Szczukowski, S.; Tworkowski, J.; Bieniek, A., 2013: Dendromass derived from agricultural land as energy feedstock. Pol. J. Environ. Stud., 22 (2): 511-520.

28. Szczepanowska, H. B., 2001: Drzewa w mieście. Warszawa, Hortpress, pp. 256 (in Polish).

29. Ślusarczyk, T., 2012: Lasy robiniowe ostoją rzadkich i zagrożonych grzybów wielkoowocnikowych. Prz. Przyrodniczy, 23 (2): 11-41 (in Polish).

30. Tsakov, H.; Alexandrov, A., 2005: Growth of Robinia pseudoacacia L. on a reclaimed terrain in Bulgaria studied over a period of climatic anomalies. Folia Oecologica, 32 (1): 1-5.

31. Wang, L.; Zhang, Q.; Shao, M.; Wang, Q., 2013: Rainfall interception in a Robinia pseudoacacia forest stand: estimates using gash's analytical model. J. Hydrol. Eng., 18: 474-479 http://dx.doi.org/10.1061/(asce)he.1943-5584.0000640.

32. Walkovszky, A., 1998: Changes in phenology of the locust tree (Robinia pseudoacacia L.) in Hungary. Int. J. Biometeorol., 41: 155-160 http://dx.doi.org/10.1007/s004840050069.

33. Wojda, T.; Klisz, M.; Mionskowski, M., 2014: Robinia akacjowa w Polsce - obca, ekspansywna, ale nie bez wartości! Notatnik Naukowy IBL 1(96).

34. Zajączkowski, K.; Wojda, T., 2012: Robinia akacjowa Robinia pseudoacacia L. w gospodarczej uprawie plantacyjnej. Studia i Materiały CEPL w Rogowie, 33 (4): 130-135 (in Polish).

35. Zhang, J.; Guo, B.; Jiang, O.; Ru, H.; Wang, Z., 2013: Study on microclimate characteristics and vertical variation of potential evapotranspiration of the Robinia pseudoacacia forest in the loess plateau of China. Advances in Meteorology http://dx.doi.org/10.1155/2013/748418.

\section{Corresponding address:}

\section{Professor ROBERT KALBARCZYK, Ph.D.}

Wrocław University of Environmental and Life Sciences

Faculty of Environmental Engineering and Geodesy Institute of Landscape Architecture Grunwaldzki Square 24a

50-363 Wrocław, POLAND

e-mail: robertkalbarczyk@wp.pl or robert.kalbarczyk@up.wroc.pl 